\title{
Smart Mobility and Cities: A Study From Toronto-On
}

\author{
Guilherme Bridi ${ }^{1}$, Emanuelle Soares dos Santos $^{2} \&$ Elenara Viera de Viera ${ }^{2}$ \\ ${ }^{1}$ Department of Tourism, DETUR, Federal University of Rio Grande do Norte, UFRN, Natal/RN, Brazil \\ ${ }^{2}$ IPA, Methodist University Center, Porto Alegre/RS, Brazil \\ Correspondence: Dr. Guilherme Bridi, Department of Tourism, DETUR, Federal University of Rio Grande do Norte, \\ UFRN, Natal/RN, Brazil.
}

Received: January 12, 2020

Accepted: January 29, 2020

Online Published: January 31, 2020

doi:10.5430/ijba.v11n1p35

URL: https://doi.org/10.5430/ijba.v11n1p35

\begin{abstract}
This study aimed to identify the positive and negative aspects of urban mobility in Toronto, highlighting the importance of ICT's Information Technologies and describe which aspects of urban mobility are characteristic of smart mobility. The sample consisted of 118 citizens who answered a structured questionnaire. The results indicate that Toronto's urban mobility has several aspects that fulfill the smart mobility requirements, especially projects and investments in improving infrastructure, safety, and accessibility, as well as innovation and sustainability actions that benefits citizens and tourists. Nevertheless, improvements are still needed in community-manager interactivity platforms and transportation costs, especially for the low-income population.
\end{abstract}

Keywords: smart mobility, transportation, ICT's, smart cities, tourism, Toronto

\section{Introduction}

Cities are considered the main urban and social spaces since the Industrial Revolution of 1840, once they gather industries, jobs, products and services (Dumazedier, 1980). During the twentieth century, the world observed the ungoverned growth of large urban centers, causing different problems, such as pollution, increased crime rates, chaotic traffic, mobility difficulties, etc. (Reis, Andrade, Santos, Lima, \& Paixão, 2019).

The technological revolution or the fourth industrial revolution, between the late twentieth and early twenty-first centuries, made it possible to reconfigure new social structures, such as the media, marketing, and consumption of products and services, creating new paradigms of teaching and professions in the light of technology. This revolution helped to spread the terms 'smart things' and 'smart world', which in turn introduced the terms 'smartphones', 'smart cards', 'smart televisions', etc. We live, actually, in a "smart age” (Lyons, 2018; Ma et al., 2005).

This "smart" reality also fits in the cities, since, through the use of technologies, sustainable and effective solutions to solve its urban, economic, social and environmental problems are increasingly being improved, giving rise to the Smart City concept (Battarra, Gargiulo, Tremiterra, \& Zucaro, 2018; Lemos, 2013; Papa, Galderisi, Majello, \& Saretta, 2015; Soupizet, 2017).

Some classical authors believe that to understand the scope of the term 'smart city' it is required to divide it into categories: Environment; Governance; Economy, People, Experiences and Mobility (Giffinger et al., 2007). On the other hand, Frost and Sullivan (2012) consider that a smart city includes eight smart categories: Smart Governance, Smart Energy, Smart Building; Smart Infrastructure, Smart Technology, Smart Healthcare, Smart Citizen and, of course, Smart Mobility.

The urban mobility, in the context of a smart city, is a very complex issue, not only for its effects in the structure of the city but also as a main factor for the development of businesses in the city area (Jönson \& Tengström, 2006). Urban mobility is the transportation and displacement of people, products and services that, with the aid of information technologies (ICT's), become the contemporary word 'smart mobility' (Battarra et al., 2018; Frost \& Sullivan, 2013; Lam \& Head, 2012).

Smart mobility is an automated, personalized, connected, on-demand and sustainable mobility and is one of the most growing lucrative markets, with an estimated global market value of US\$ 1.17 trillion by 2025 (Docherty, Marsden, \& Anable, 2018; Lyons, 2018). Its scope is based on four dimensions: vehicle technology, Intelligent Transport Systems (ITS), data and new mobility services (Jeekel, 2017); 
To configure a Smart mobility scenario, the mobility of people and goods has to be provided in a smart manner, which means the integration of all transport modes, ICT solutions, no pollution and congestions (Nemtanu Schlingensiepen, Buretea, \& Iordache, 2016). In this scenario, the development of smart mobility actions is one of the most sustainable ways for transport systems seeking to adapt to this trend, especially in large urban centers (Lyons, 2018; Staricco 2013).

As an example, Helsinki, Finland announced that, by 2025, the city plans are to make it unnecessary for any resident to own a car. This goal is part of an on-demand mobility system that would allow customers to choose among public and private transport providers and assemble the fastest or cheapest way of getting anywhere at any time (Viechnicki, Khuperkar, Fishman, \& Eggers, 2015).

Toronto is not an exception to this rule. Improvements in mobility structures and programs have been observed in the city over the last few years. An example of improvements is the revitalization of Union Station, the main city transportation hub (US \$ 640 million budget), which made it possible for citizens and tourists to enjoy subway, municipal and intercity trains, bus, airport shuttle, taxi and bicycle in an integrated way (City of Toronto, 2019).

However, despite this infrastructure and the investment already made in Toronto, it is essential to develop studies that can characterize, from the viewpoint of transport users, which are the positive aspects and current challenges of the city's urban mobility. Thereby, it will be possible to establish how close (or not) the city is to the smart conceptions.

Thus, this study focuses on mobility and transportation in smart cities. It aims to identify the positive and negative aspects of urban mobility In Toronto, highlight the importance of ICT's Information Technologies to provide solutions for this subject and characterize which are the main aspects of urban mobility that could be properly considered smart.

\section{Smart Cities and Smart Mobility}

The relationship between cities and information technology began in classical antiquity. About six thousand years ago, the invention of writing validated the commercial, political and religious relations of the time, and was considered the first resource of humanity information technology (Townsend, 2013).

Excessive population concentration in cities is considered a recent phenomenon since in the 18th century, only 5\% of the population lived in cities (Owen, 2009). The city, as an urban and social space, got a lot of strength during the twentieth century. The urban population increased from 746 million to 5 billion between 1950 and 2015 (Peprah, Amponsah, \& Oduro, 2019; UN-Desa, 2017; UN-Habitat, 2016;). The estimates for 2100 indicate that the world's population will reach 10 billion people, and eight billion will live in cities (Townsend, 2013).

The people concentration in cities provokes many side effects, among them, the escalation of urban problems, the excessive emission of toxic and polluting gases, traffic jams, increased poverty indicators, etc. (Peprah et al., 2019). These negative effects manifest the need to rethink the structures and redesign the city's role. Thus, ICT's can help to find ways to reduce these consequences through smart solutions, making room for a new city conception, the 'smart cities'.

The term 'smart cities' arose in big information technology companies, related to innovative solutions to fix the old mistakes in the context of urban congestion, health, and climate warming, planning, development and operation of the cities (Harrison \& Donnelly, 2011; Soupizet, 2017).

Many cities call themselves 'smart', but they do not have proper criteria and parameters that justify this self-classification. To be considered smart, a city needs to be able to integrate and synthesize elements for specific purposes, such as improving its efficiency, sustainability, equity and quality of life (Batty et al., 2012; Hollands, 2008; Rosa, 2018). The basis for building a smart city lies in a perfect and intelligent combination of self-reliant and independent citizens aware of their roles in society (Giffinger et al., 2007).

Smart cities have well-recognized aspects that generally based on three core things: "economic development, reducing the environmental footprint and improving the quality of life of citizens, making use of available technologies, particularly." (Soupizet, 2017, p. 10).

Harrison and Donnelly (2011) understand smart cities from the benefits that Information Technologies can provide to these spaces, and highlight the following: a) reduction of water and energy consumption and, consequently, drop of carbon dioxide emissions into the atmosphere; b) improved use of pre-existing infrastructure; c) new services offering to citizens and transport users, such as real-time spatial orientation (GPS and virtual maps) and better use of transport and mobility options; d) stimulation of commercial transactions based on the real-time disclosure of the 
city's service operations. The importance and performance of ICTs in the field of transport have been long-standing, especially regarding the aid of traffic control, satellite navigation systems, etc. (Starico, 2013).

Effective, integrated, shared, technological, sustainable and non-polluting urban mobility is an essential component of a smart city (Ning, Xia, Ullah, Kong, \& Hu, 2017; Yigitcanlar \& Kamruzzaman, 2019). Despite of the different meanings attributed to the concept over the past few years (Albino, Berardi, \& Dangelico, 2015), the term 'smart mobility' refers to the potential of optimizing city infrastructure, services, and urban behavior through the use of digital networks to create conditions for a constant process of learning and innovation (Campbell, 2012; Papa \& Lauwers, 2015).

Researches have different approaches regarding smart mobility, but the main two are the "techno-centric", based on the application of ICT's to transport and infrastructure and the "consumer-centric", that refers to new mobility products for transport users (Papa \& Lauwers, 2015).

Mobility is effectively smart when it concentrates on the ecological sustainability of the city or when it aims to enforce data and knowledge available. That's why the use of ICT's is essential for smart mobility (Benevolo, Dameri, \& D'auria, 2016; Papa \& Lauwers, 2015; Peprah et al., 2019).

If Smart Mobility means extensive use of ICT's into transport system, the integration between "smartness" and sustainability of urban mobility can be achieved, at the same time, through the use of strategies, devices, and innovations that make the transport system more compatible with the urban environment (Battarra et al., 2018). Urban planning is the best way to achieve smart mobility, since it moves the transportation focus from individual to collective mode, through the extensive use of ICT's (Letaifa, 2015)

Smart Mobility initiatives aim to achieve six objectives that involve: a) reducing pollution, b) reducing noise pollution, c) reducing traffic congestion, d) reducing transfer costs, e) improving transfer speed, and f) increasing people safety (Bencardino \& Greco, 2014; Lawrence, Kavage, \& Litman, 2006; Peprah et al., 2019).

Therefore, Smart Mobility is not only aimed at making urban mobility more sustainable but is a useful mean for both transcending distance and optimizing traffic flows. At the same time, it aims to receive citizen feedback about live ability in cities and the quality of public transport services (Battarra et al., 2018; Benevolo et al., 2016; Lyons, 2018). The smart mobility concept is not just limited to the diffusion of ICT's since it should also consider people and community welfare. Therefore, reducing costs and improving the quality of the transportation should be (theoretically) core concerns of smart mobility planners (Docherty et al., 2018; Papa \& Lauwers, 2015).

Increasing tourism development is another reason for investing on smart mobility, since, with the help of ICT's, current tourist consumers are becoming each day, more independent of classical stakeholders (travel agencies, tour guides, etc.) enhancing the value of personal experiences, such as taking destinations public transports (Khan, Woo, Nam, \& Chathoth, 2017; Tripathy, Tripathy, Ray, \& Mohanty, 2018).

\section{Mobility in Toronto}

Located in Ontario province, Toronto is the biggest city in the country, with a 2.93 million population. The city is also the core center of the six million people that live in its metropolitan area (Un-Desa, 2017). With more than 43 million tourists annually, Toronto is the leading tourism destination in Canada (City of Toronto, 2019). Therefore, create and promote smart, fast, safe and sustainable transportation becomes an essential matter regarding public policies and government agenda.

Public players are investing in new infrastructure and technology to keep traffic moving and to improve the transportation system for all road users. The launch, in 2015, of the 2016-2020 Congestion Management Plan is a nice example that stakeholders are prioritizing solutions for traffic problems (City of Toronto, 2015).

Since October 2017, the urban innovation organization named Sidewalk Labs is s designing a district in Toronto's Eastern Waterfront called Sidewalk Toronto, to fight urban growth problems, working in partnership with the tri-government agency Waterfront Toronto and the local community (Sidewalk Toronto, 2019). Regarding mobility issues, the Sidewalk Toronto aims to provide: safer bike and pedestrian-friendly streets, transport sharing, self-driving vehicles and adaptive traffic signals at an affordable price.

Many other actions and achievements can be pointed towards the development of urban mobility in Toronto. The revitalization of Canada's biggest transportation hub, Union Station, is a fine case on how mobility became a major concern for Torontonians. The Station is a huge part of Toronto's history, with more than 150 years old. Connecting Toronto both on a regional and national scale by rail, buses, subway, and streetcar, currently, it hosts big mobility players like Via Rail Canada, GO Transit and UP express (City of Toronto, 2019). 
The revitalization of the Union Station is based on three objectives: 1) Improving the quality and capacity of pedestrian movement; 2) Restoring heritage elements; 3) Transforming the station into a major center for visiting, dining and shopping (City of Toronto, 2019). A special event of this innovation process was the conception, in 2015, of the Union Pearson Express line for providing fast, safe and comfortable transportation between downtown and the international airport.

Toronto also has the TTC - Toronto Transit Commission portal, which provides information on lines, routes, times, spatial location, maps, integrated fares, and the user passes. There is also real-time information on city traffic and urban mobility conditions (TTC, 2019).

As another illustration of Toronto's mobility activities is the establishment of the Downtown Mobility Strategy, coordinated by several divisions and public agencies. With the help of the ICT's, the project seeks to provide a safe, efficient and more sustainable travel for residents, workers, students and visitors of Downtown. Main actions include: reflect current and future uses; prioritize Road Space; increase space for lingering; improve safety, increase flexibility and adaptability and promote smart commute (City of Toronto, 2018).

Seeking to prepare Toronto for future scenarios, the city's Council has approved the Automated Vehicles (AV) Tactical Plan and Readiness 2022 report, which is the first plan of its kind in North America. The automation into commercial and passenger vehicles will play a main role in the future of the urban transportation because many experts believe that it could improve traffic safety and provide greater access to mobility for those who do not or cannot drive, as well as enhance the transportation network (City of Toronto, 2019).

\section{Methods}

This research has a quantitative cross-sectional and exploratory approach. In quantitative studies, the researcher uses conceptual frameworks, formulates hypotheses regarding the studied events and analyzes their data through statistics (Dalfovo, Lana, \& Silveira, 2008).

A virtual and structured questionnaire with closed questions was used to collect data from a statistical sample of 118 individuals (the city residents for a maximum of two years). This sample selection criterion was used because Toronto is the fastest growing city in Canada and U.S. Figure 01 shows that the city's population grew by 77,435 persons from July 2017 to July 2018 (Clayton \& Shi, 2019; U.S. Census Bureau, 2019). Therefore, the sample composition was based on the assumptions of quantitative tradition, with $95 \%$ confidence and $9 \%$ sampling error, considering the city population growth during the last two years.

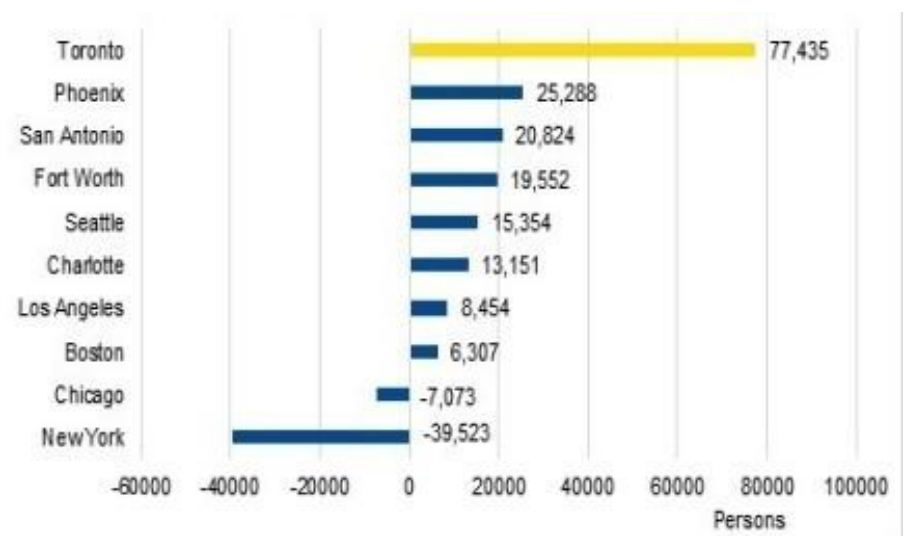

Figure 1. Numeric population growth from July 2017 to July 2018

Source: Based on data from Clayton and Shi (2019)

The survey was posted on social networks, in specific virtual groups for residents of Toronto city. These groups had moderators who performed a prior analysis of the instrument before making it available to their members. The insertion of the questionnaire and the invitation to participation occurred weekly, between February and November 2019. After data collection, the results were allocated in the SPSS statistical software to quantify the outcomes. The data description was made by absolute (n) and relative (\%) frequencies for qualitative variables, and by average and standard deviation (SD) for quantitative variables. 


\section{Results}

The first part of the questionnaire aimed to identify the participant's sociodemographic profile. The majority of respondents were female (72\%) and the age group from 20 to 40 years old was predominant in both genders (Figure 2).

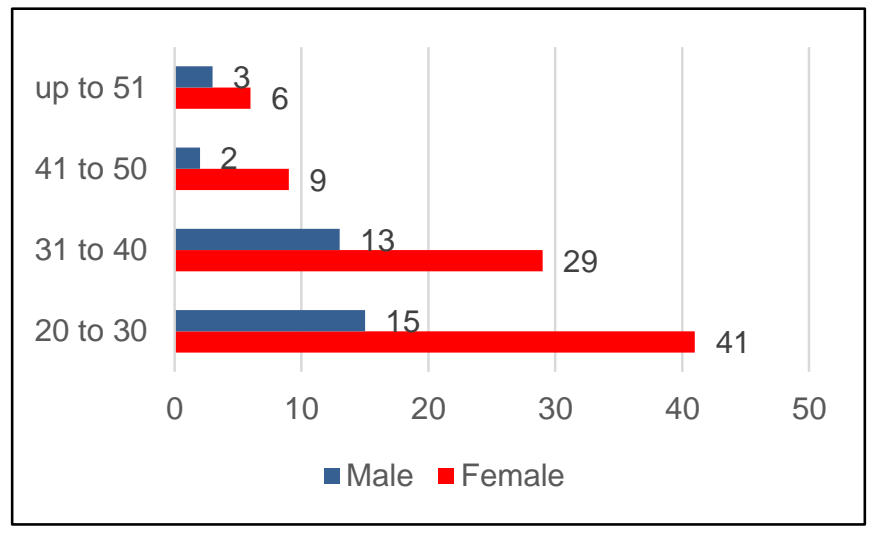

Figure 2. Gender and age

Source: Authors elaboration (2019)

Regarding residence time and its relationship with age, almost 50\% of individuals have lived in Toronto for over 6 months, especially those between 20 and 40 years old. The residence time in the city ranged from one to two years (Figure 3).

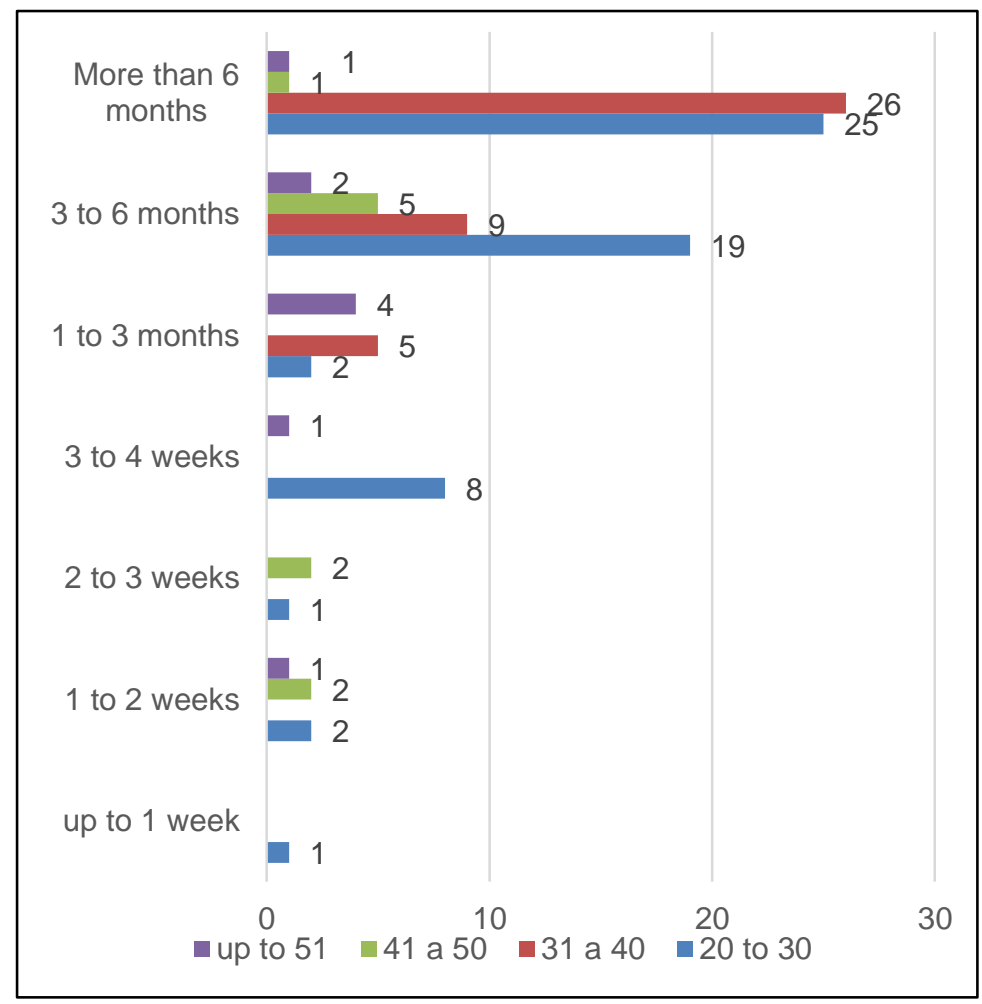

Figure 3. Residence time and age

Source: Authors elaboration (2019) 
The second part of the questionnaire specifically asked about the quality of digital technologies and services associated with the city's urban mobility. Ten assertions (S1 to S10) were written about this subject (Table 1) for recording the respondent's opinion on a Likert scale from 1 to $7(1=$ strongly disagree and $7=$ strongly agree $)$, as shown in Table 1.

Table 1. Answer converter

\begin{tabular}{cc}
\hline Value & Meaning \\
\hline & Total Discordance Range \\
Partial Discordance Range
\end{tabular}

Neutral Range

Partial Accordance Range

Total Accordance Range

\begin{tabular}{cc}
\hline 1 & Strongly disagree \\
\hline 2 & Disagree \\
\hline 3 & Partially disagree \\
\hline 4 & I do not agree nor disagree \\
\hline 5 & Partially agree \\
\hline 6 & Agree \\
\hline 7 & Strongly agree \\
\hline
\end{tabular}

Source: Authors elaboration (2019)

Table 2. Digital services to users

\begin{tabular}{llll}
\hline Statements & $\mathbf{N}$ & Mean & SD \\
\hline S1 & $\begin{array}{l}\text { The city offers free APPs with information about destinations, } 118 \\
\text { restaurants, cultural life, etc. }\end{array}$ & 5.33 & 1.854 \\
\hline S2 & $\begin{array}{l}\text { The city has social networks with information about destinations, } \\
\text { restaurants, cultural options, etc. }\end{array}$ & 5.57 & 1.712 \\
\hline S3 & $\begin{array}{l}\text { The city offers free APPs for newcomer's and tourists assistance, } 118 \\
\text { with maps, information about hospitals, police stations, etc. }\end{array}$ & 4.78 & 1.975 \\
\hline S4 & The city offers free APPs in the scope of security for emergencies. 118 & 4.56 & 1.874 \\
\hline S5 & Public places have free internet & 5.03 & 1.800 \\
\hline S6 & $\begin{array}{l}\text { The population reaches public management to provide feedback for } \\
\text { future improvements. }\end{array}$ & 4.70 & 1.671 \\
\hline S7 & $\begin{array}{l}\text { Public management is committed to promote sustainability actions } \\
\text { for the city. }\end{array}$ & $\mathbf{5 . 5 5}$ & $\mathbf{1 . 5 6 1}$ \\
\hline S8 & $\begin{array}{l}\text { Information and Communication Technology (ICT) projects seek to } \\
\text { improve quality of life, security, etc. }\end{array}$ & 5.11 & 1.642 \\
\hline S9 & $\begin{array}{l}\text { Public management is committed to provide easy access to digital } \\
\text { services for low-income residents. }\end{array}$ & 4.83 & 1.813 \\
\hline S10 & $\begin{array}{l}\text { Public management seeks to enhance creativity and innovation in } \\
\text { the city. }\end{array}$ & $\mathbf{5 . 3 6}$ & $\mathbf{1 . 5 5 5}$ \\
\hline
\end{tabular}

Source: Authors elaboration (2019). 
Table 2 shows that most of the averages were above the scale central cut-off point (grade 4). There was no overall agreement in any of the assertions (grade 7). The highest averages and lowest standard deviations were observed in questions S7 and S10. 62\% of respondents scored 6 or 7 (totally agree) to question S7, and $74.6 \%$ of participants partially or totally agreed (between 5 and 7) with question S10.

The lowest average was found in question S4: 52.5\% of respondents scored 1 to 4. Question S6 results are a little above the central cut-off point, $34 \%$ complete that they do not agree or disagree with it (grade 4).

The third part of the questionnaire, consisting of 10 statements (S11 to S20), addressed the transport and urban mobility system, as follows in Table 3 .

Table 3. Urban mobility

\begin{tabular}{lllll}
\hline Statements & N & Mean & SD \\
\hline S11 & The city has an efficient public transportation system. & 118 & 5.52 & 1.567 \\
\hline S12 & The city shares valuable information about public transportation. & 118 & $\mathbf{5 . 9 1}$ & $\mathbf{1 . 3 2 0}$ \\
\hline S13 & Public transportation is handicap accessible. & 118 & $\mathbf{5 . 9 7}$ & $\mathbf{1 . 4 7 0}$ \\
\hline S14 Improvements in signs, plates and traffic lights are still required. & 118 & 4.31 & 2.163 \\
\hline S15 & Population is committed to sustainable mobility. & 118 & 5.25 & 1.701 \\
\hline S16 & Population helps on seeking solutions for urban mobility issues. & 118 & 4.95 & 1.684 \\
\hline S17 & There are movement disabilities around the city. & 118 & $\mathbf{3 . 9 8}$ & $\mathbf{2 . 0 5 5}$ \\
\hline S18 & $\begin{array}{l}\text { Public management is committed to enhance urban mobility } \\
\text { services through information technology. }\end{array}$ & 118 & 5.01 & 1.656 \\
\hline S19 & Low income residents have easy access to public transportation. & 118 & 4.64 & 1.973 \\
\hline S20 & The city offers real-time traffic information and safety APPs. & 118 & 5.13 & 1.920
\end{tabular}

Source: Authors elaboration (2019).

Statement S11, which questions the efficiency of the city's transportation system, obtained $77.1 \%$ of answers between concepts 5 to 7. The highest averages and lowest standard deviations were found in the S12 and S13 assertions. Only $0.8 \%$ of respondents totally disagreed (grade 1) with S12, while 67\% scored 6 or 7. Question S13 received $84.7 \%$ of their answers between grades 5 to 7 .

Assertion S14 had different rates: $50 \%$ of respondents scored grade 5 to 7 (agreement) and another $40 \%$ scored between grade 01 to 03 (disagreement). S15 results reached $72 \%$ agreement (grades 5 to 7 ) by respondents. Statement S17 obtained the lowest average and one of the largest standard deviations: $18.6 \%$ of respondents strongly disagree while $16.1 \%$ totally agree with it. The other scores were divided almost uniformly between the scales 2 to 6 , once the average was close to scale 4 (neutral).

In assertion S18, 64.3\% of participants scored grade 5 to 7 and $18.6 \%$ remained neutral (grade 4). S19 diverged in the incidence of the responses, $22.4 \%$ indicated neutrality, $55.1 \%$ scored in the agreement range and $22.5 \%$ in the disagreement range. In the end, $61.9 \%$ of respondents agreed with statement S20.

\section{Discussion}

This study aimed to identify the strengths and weaknesses of urban mobility in Toronto, highlighting the importance of using ICTs, as well as mapping possible convergences between city mobility and smart mobility characteristics.

First, the analysis of the results in Table 1 indicate that issues related to public management actions on sustainability, creativity, and innovation of urban mobility in Toronto received the highest evaluations (S2, S7, and S10), subjects that are essential to the smart mobility logic (Battarra et al., 2018; Papa \& Lauwers, 2015). These results also reveal the effectiveness of plans and projects designed to provide innovations in the city's urban mobility structures and services, such as the Downtown Mobility Strategy, Union Station improvement, the 2016-2020 Congestion Management Plan and the Sidewalk Toronto, cited above. 
However, the results from Table 1 also indicate that some points for smart mobility consolidation in the city still need attention. Free internet in public spaces (S5) received only partial agreement (5.03), pointing out that this aspect is not yet fully addressed for a part of the population. The assessment of the safety provision and emergency APPs (S4) as well as the information assistance to new residents and tourists (S3) reached neutrality range, indicating that mobile communication resources may not be operating properly in the city, especially for assisting newcomers and visitors.

This result is of concern, especially because the city receives a significant number of new residents each year and is also considered Canada's main tourism destination. This finding also confronts the assumptions of authors who consider that the use of ICT's and communication resources is essential for smart mobility diffusion (Benevolo et al., 2016; Nemtanu et al., 2016; Papa \& Lauwers, 2015; Peprah et al., 2016; Starico, 2013).

Population feedback to managers (S6) also got a neutral range. This draws attention once it reveals the existence of interactivity barriers between the different actors. These outcomes move in the opposite direction of what was proposed by Battarra et al. (2018), Benevolo et al. (2018) and Lyons (2018), who emphasize the importance of integrated communication and constant feedback between public managers and the community. Other aspects can be added to this discussion, such as the statement $\mathrm{S} 9$ results (neutrality range and high standard deviation) that reveal low-income population difficulties of access to digital services, contrary to the smart logic sustainable precepts.

Secondly, the analysis of the results in Table 2, concludes that information sharing, transport efficiency and accessibility for people with disabilities are the main strengths of Toronto's urban mobility (S11, S12, and S13). The population's concern with the adequacy of transportation systems and sustainability precepts (S15) also received one of the highest averages of agreement, reinforcing the assertion S7 results, which has a similar theme.

The positive evaluation of these factors aligns with the smart mobility characteristics regarding the importance of providing sustainable mobility actions and structures for the population well-being, such as the shared use of means of transport and the use of clean and renewable energy (Bencardino \& Greco, 2014; Lawrence et al., 2006; Nemtanu et al., 2016; Peprah et al., 2016).

Among all the assertions, the one that investigated whether or not there are difficulties in locomotion in Toronto (S17) was the one that received the most controversial answers, and the average value of the results remained within the neutral range. These findings highlight the existence of different scenarios for the city's new residents. An explanatory hypothesis for this result suggests that the new citizens (subjects of this research) are located in diverse neighborhoods, leading them to use distinct means of transport to travel different distances. Another hypothesis is that these individuals belong to different socioeconomic statuses, which sometimes makes them have antagonistic views on the same reality.

The statement S19 result corroborates this discussion because addresses the easy access of the low-income population to transportation. This question received one of the lowest averages and one of the largest standard deviations, indicating that a portion of the population considered that the cost of transportation in the city is high, stepping up the hypothesis that these residents find themselves in different socioeconomic realities. This scenario doesn't match the concepts of smart mobility that support the importance of providing affordable transportation for all users (Papa \& Lauwers, 2015; Docherty et al., 2018).

Assertions S18 and S20, which addressed, respectively, the use of ICT's to improve urban mobility services and the provision of APP's for real-time traffic information access, showed results in the partial agreement range. These findings add the results of S3, S4, and S5 and suggest that by smart mobility standards, the use of ICT's in urban mobility services in Toronto still needs improvements.

Statement S14, regarding improvement in signs and traffic lights, produced conflicting and adverse answers from participants. S14 presented the second-lowest overall mean and the highest standard deviation value. The low score assign to this statement increases the importance of the Sidewalk Toronto project, which has as one of its main roles the provision of improvements in city signs (Toronto, 2019).

Overall, the results show that the urban mobility landscape in Toronto is positive. Issues involving accessibility (physical), sustainability, efficiency, and innovation achieved the best averages, confirming that the projects, reformulations, and investments made by public and private management in the sector during the last years have been well evaluated by the population.

The relationship between this context and the smart mobility characteristics and objectives (Bencardino \& Greco, 2014; Lawrence et al., 2006; Nemtanu et al., 2016; Peprah et al., 2016) disclose that Toronto has full conditions for appearing on the list of cities that organize their transport and mobility system under these parameters, especially 
regarding the reduction of pollutants, noise pollution and congestion, the increase of safety and travel speed, and users well-being.

However, the results also show that there are challenges to be overcome. The use of ICT's and the quality of digital services and APP's are not yet good enough for part of the population. The answers indicate that digital services tend to provide more cultural and leisure options than real-time city transport services. Thus, it is imperative to seek investments and necessary improvements, making use of ICT's as essential tools for smart mobility.

\section{Conclusion}

The survey results conclude that urban mobility in Toronto is about to become smart. There are several projects and investments related to improvements in structures, safety, speed and employment of sustainable transport resources. In general, the population perceives these advances, especially regarding handicap accessibility, innovation and creativity actions that aim to improve commuting in the city.

However, to get even closer to the smart mobility precepts, the city needs to improve the use of ICT's for information services, reduce the transportation cost for the low-income population, and improve communication, interactivity and feedback channels between population and urban mobility managers.

This study has some limitations. Participants' socioeconomic information and education level were not collected, which would certainly provide more data about the sample and could improve the discussion section. Individuals nationality could also provide the elaboration of distinct scenarios. Future studies should collect this information for more complete findings.

However, the results obtained allow developing new insights on the smart reality of urban mobility in large centers, especially regarding the convergence (or not) between the actions of their managers and the opinion of the resident population.

Although the results present a positive outlook, the reality of Toronto reinforces the idea that projects, ICT's and mobility structures are not enough for a city's mobility to be considered smart. It is necessary to go beyond this logic.

Interactivity, inclusion and public and private partnership programs are also necessary to develop further democratizing access to transportation in the city, allowing citizens to exercise their key role as a facilitator to social development. Well, that's smart!

\section{References}

Albino, V., Berardi, U., \& Dangelico, R. M. (2015). Smart Cities: Definitions, dimensions, performance, and initiatives. Journal of Urban Technology, 22(1), 3-21. https://doi.org/10.1080/10630732.2014.942092

Battarra, R., Gargiulo, C., Tremiterra, M. R., \& Zucaro, F. (2018). Smart mobility in Italian metropolitan cities: A comparative analysis through indicators and actions. Sustainable Cities and Society, 41, 556-567. https://doi.org/10.1016/j.scs.2018.06.006

Batty, M., Axhausen, K. W., Giannotti, F., Pozdnoukhov, A., Bazzani, A., Wachowicz, M., ... Pôrț̂yālî, Y. (2012). Smart cities of the future. The European Physical Journal Special Topics, 214, 481-518. https://doi.org/10.1140/epjst/e2012-01703-3

Bencardino, M., \& Greco, I. (2014). Smart Communities. Social Innovation at the Service of the Smart Cities. TeMA Journal of Land Use, Mobility and Environment. https://doi.org/10.6092/1970-9870/2533

Benevolo, C., Dameri, R. P., \& D'auria, B. (2016). Smart mobility in smart City. Action taxonomy, ICT intensity and public benefits. In T. Torre, A. Braccini, \& R. Spinelli (Eds.), Empowering organizations: Enabling platforms and artefacts, lecture notes in information systems and organisations (pp. 13-28). Cham: Springer. https://doi.org/10.1007/978-3-319-23784-8_2

Campbell, T. (2012). Beyond Smart City: How cities network, learn and innovate. Earthscan, NY.

City of Toronto. (2015). 2016-2020 Toronto's Congestion Management Plan. Retrieved from https://www.toronto.ca/wp-content/uploads/2018/01/96a1-CMP-2016-2020_Final_Nov20_Web-a.pdf

City of Toronto. (2018). Downtown Mobility Strategy Plan 2018. Retrieved from https://www.toronto.ca/wp-content/uploads/2018/04/9700-downtown-mobility-strategy-city-panning.pdf

City of Toronto. (2019). Union Station revitalization project. Retrieved from https://www.toronto.ca/services-payments/venues-facilities-bookings/booking-city-facilities/union-station/union -station-revitalization-milestones/ 
Clayton, F., \& Shi, H. Y. E. (2019, May 31). Wow! Toronto was the second fastest growing metropolitan area and the top growing city in all of the United States and Canada. Retrieved from https://www.ryerson.ca/cur/Blog/blogentry35/

Dalfovo, M. S., Lana, R. A., \& Silveira, A. (2018). Métodos quantitativos e qualitativos: um resgate teórico. Revista Interdisciplinar Científica Aplicada, 2(4), 1-4.

Docherty, I., Marsden, G., \& Anable, J. (2018). The governance of smart mobility. Transportation Research Part A: Policy and Practice, 115, 114-125. https://doi.org/10.1016/j.tra.2017.09.012

Dumazedier, J. (1980). Valores e conteúdos culturais do lazer. São Paulo: Sesc.

Frost, \& Sullivan. (2013). Strategic opportunity analysis of the global smart city market. Retrieved from https://dsimg.ubm-us.net/envelope/153353/295862/1391029790_strategic_opportunity. pdf

Giffinger, R., Fertner, C., Kramar, H., Kalasek, R., Pichler-Milanović, N., \& Meijers, E. (2007). Smart Cities: Ranking of European Medium-Sized Cities. Centre of Regional Science (SRF). Vienna University of Technology. Retrieved from http://curis.ku.dk/ws/files/37640170/smart_cities_final_report.pdf

Harrison, C., \& Donnelly, I. A. (2011). A theory of smart cities. Proceedings of the 55th Annual Meeting of the ISSS-2011, 55(1), 17-22.

Hollands, R. G. (2008). Will the real smart city please stand up? Intelligent, progressive or entrepreneurial?. City, 12(3), 303-320. https://doi.org/10.1080/13604810802479126

Jeekel, H. (2017). Social sustainability and smart mobility: Exploring the relationship. Transportation Research Procedia, 25, 4296-4310. https://doi.org/10.1016/j.trpro.2017.05.254

Jönson, G., \& Tengström, E. (2006). Urban transport development: A complex issue. Springer Science \& Business Media.

Khan, S. M., Woo, M., Nam, K., \& Chathoth, K. P. (2017). Smart City and Smart Tourism: A Case of Dubai. Sustainability, 9(12), 2279. https://doi.org/10.3390/su9122279

Lam, D., \& Head, P. (2012). Sustainable urban mobility. In O. Inderwildi, \& D. King (Eds.), Energy, Transport, \& The Environment (pp. 359-371). London: Springer. https:// doi.org/10.1007/978-1-4471-2717-8_19

Lawrence, F., Kavage, S., \& Litman, T. (2006). Promoting public health through smart growth: building healthier communities through transportation and land use policies and practices. The National Academies of Sciences, Engineering, and Medicine. Retrieved from https://www.vtpi.org/sgbc_health.pdf

Lemos, A. (2013). Cidades inteligentes. GV Executivo, $12(2), \quad 46-49$. https://doi.org/10.12660/gvexec.v12n2.2013.20720

Letaifa, S. B. (2015). How to strategize smart cities: Revealing the SMART model. Journal of Business Research, 68(7), 1414-1419.

Lyons, G. (2018). Getting smart about urban mobility: Aligning the paradigms of smart and sustainable. Transportation Research Part A: Policy and Practice, 115, 4-14. https://doi.org/10.1016/j.tra.2016.12.001

Ma, J., Yang, L., Apduhan, B., Huang, R., Barolli, L., \& Takizawa, M. (2005). Towards a smart world and ubiquitous intelligence: A walkthrough from smart things to smart hyperspaces and UbicKids. International Journal of Pervasive Computing and Communications, 1(1), 53-68. https://doi.org/10.1108/17427370580000113

Nemtanu, F. C., Schlingensiepen, J., Buretea, D., \& Iordache, V. (2016). Mobility as a service in smart cities. Responsible Entrepreneurship Vision, Development and Ethics, 425-435.

Ning, Z., Xia, F., Ullah, N., Kong, X., \& Hu, X. (2017). Vehicular social networks: Enabling smart mobility. IEEE Communications Magazine, 55(5), 16-55. https://doi.org/10.1109/MCOM.2017.1600263

Owen, D. (2009). Green metropolis: why living smaller, living closer, and driving less are the keys to sustainability. New York: Riverhead Books.

Papa, E., \& Lauwers, D. (2015). Smart mobility: Opportunity or threat to innovate places and cities. Paper Presented at the 20th International Conference on Urban Planning and Regional Development in the Information Society. Retrieved from http://repository.corp.at/36/ 
Papa, R., Galderisi, A., Majello, M. C., \& Saretta, E. (2015). Smart and Resilient Cities. A Systemic Approach for Developing Cross-sectoral Strategies in the Face of Climate Change. TeMA Journal of Land Use, Mobility and Environment, 8(1), 19-49. https://doi.org/10.6092/1970-9870/2883

Peprah, C., Amponsah, O., \& Oduro, C. (2019). A system view of smart mobility and its implications for Ghanaian cities. Sustainable Cities and Society, 44, 739-747. https://doi.org/10.1016/j.scs.2018.10.025

Reis, M. F., Andrade, P. T., Santos, M., Lima, A. R., \& Paixão, A. C. (2019). Smart Cities: Como o conceito de cidades inteligente pode melhorar a mobilidade urbana na cidade do Rio de Janeiro. Simpósio de Pesquisa Operacional e Logística da Marinha, 19.

Rosa, N. (2018, March 1). Smart City: A importância das disrupções tecnológicas em uma cidade inteligente. Canaltech. $\quad$ Retrieved from https://canaltech.com.br/eventos/smart-city-a-importancia-das-disrupcoes-tecnologicas-em-uma-cidade-intelige nte-109114

Sidewalk Toronto. (2019). Toronto tomorrow: A new approach for inclusive growth. Retrieved from https://www.sidewalktoronto.ca/

Soupizet, J. F. (2017). Cidades Inteligentes: Desafios para as sociedades democráticas. Coleção: ensaios democracia digital. São Paulo: Fundação Fernando Henrique Cardoso, 70.

Staricco, L. (2013). Smart mobility, opportunità e condizioni. TeMA Journal of Land Use, Mobility and Environment, 6(3), 289-354. https://doi.org/10.6092/1970-9870/_1933

Toronto Transit Commission - TTC. (2019). Retrieved from http://www.ttc.ca/

Townsend, A. M. (2013). Smart cities: Big data, civic hackers, and the quest for a new utopia. W.W. Norton \& Company.

Tripathy, A. K., Tripathy, P. K., Ray, N. K., \& Mohanty, S. P. (2018). iTour: The future of smart tourism: An IoT framework for the independent mobility of tourists in smart cities. IEEE Consumer Electronics Magazine, 7(3), 32-37. https://doi.org/10.1109/MCE.2018.2797758

U.S. Census Bureau, Population Division. (2019, April). Estimates of Resident Population Change and Rankings: July 1, 2017 to July 1, 2018 - United States - Metropolitan Statistical Area. Retrieved from https://factfinder.census.gov/faces/tableservices/jsf/pages/productview.xhtml?pid=PEP_2018_PEPANNCHG.U S24PR\&prodType $=$ table

UN-Desa - United Nations, Department of Economic and Social Affairs. (2017). World population prospects: The 2017 revision. Retrieved from https://www.un.org/development/desa/publications/world-population-prospects-the-2017-revision.html

UN-Habitat. (2016). Urbanization and development: Emerging futures. World cities report 2016. United Nations Human Settlements $\quad$ Programmer Retrieved from https://unhabitat.org/sites/default/files/download-manager-files/WCR-2016-WEB.pdf

Viechnicki, P., Khuperkar, A., Fishman, T. D., \& Eggers, W. D. (2015). Smart mobility: reducing congestion and fostering faster, greener, and cheaper transportation options. Retrieved from https://dupress.deloitte.com>articles>smart-mobility

Yigitcanlar, T., \& Kamruzzaman, M. (2019). Smart cities and mobility: Does the smartness of Australian cities lead to sustainable commuting patterns?. Journal of Urban Technology, 26(2), 21-46. https://doi.org/10.1080/10630732.2018.1476794 